\title{
IMPLEMENTASI PEMERATAAN PEMBANGUNAN DENGAN HOTEL TENTREM DAN ZEST DALAM PROGRAM CSR (CORPORATE SOCIAL RESPONSIBILITY)
}

\section{(IMPLEMENTATION OF EQUITY PLANNING WITH TENTREM AND ZEST HOTELS IN THE CSR (CORPORATE SOCIAL RESPONSIBILITY) PROGRAM)}

\author{
Safira Zata Iwana, Bakti Setiawan \\ Universitas Gadjah Mada \\ Yogyakarta \\ safirazata96@mail.ugm.ac.id
}

Diterima: 1 Agustus 2021; Direvisi: 22 Desember 2021; Disetujui: 24 Desember 2021

\begin{abstract}
ABSTRAK
Pemerataan telah digaungkan sebagai jargon baru dalam pembangunan, baik pembangunan pusat kota maupun kawasan pinggiran kota. Kota Yogyakarta memenuhi pembangunan perkotaan dengan membuka keran investasi bagi perusahaan yang dapat mendukung kegiatan pariwisata di dalam kota. Salah satunya adalah izin pembangunan hotel. Proses ini tidak terlepas dari keberadaan hotel sebagai perusahaan sosial atau Corporate Social Responsibility (CSR) yang diharapkan dapat mendukung pemerataan pembangunan di wilayah sekitarnya. CSR itu sendiri harus meningkatkan perekonomian, kualitas lingkungan, dan kualitas sosial masyarakat secara merata. Penelitian ini menggunakan metode deskriptif kualitatif dan metode pengumpulan data melalui wawancara mendalam dengan responden yang dianggap kompeten. Hasil penelitian menunjukkan bahwa terdapat perbedaan pelaksanaan program CSR di kedua hotel tersebut. Perbedaan bintang yang dimiliki kedua hotel tidak menjamin pemerataan pembangunan; penyebab internal dan eksternal lainnya mempengaruhinya. Sebagian besar program yang dihasilkan merupakan program jangka pendek dan bukan program pemberdayaan masyarakat, sehingga proses pemerataan pembangunan melalui program CSR belum tercapai.
\end{abstract}

Kata kunci: CSR, pemerataan pembangunan, hotel

\begin{abstract}
Equity has echoed as a new jargon in development-both the development of urban centers and urban village areas. The city of Yogyakarta fulfills urban development by opening up investment taps for companies that can support tourism activities within the city. One of them is a hotel development permit. This process is inseparable from the hotel's existence as a social company or Corporate Social Responsibility (CSR), which has expected to support equitable development in the surrounding area. CSR itself should improve the economy, the quality of the environment, and the social quality of the community equally. This research has used a qualitative descriptive method and data collection methods through in-depth interviews with respondents who were considered competent. The results showed that there were differences in the implementation of CSR programs in the two hotels. The difference in stars owned by the two hotels does not guarantee an even distribution of development; other internal and external causes influence it. The majority of the programs produced are short-term programs and are not community empowerment programs, so that the process of equitable development through CSR programs has not achieved.
\end{abstract}

Keywords: CSR, equitable development, hotel 


\section{PENDAHULUAN}

Pola hubungan antara perusahaan dengan masyarakat sekitar sudah mulai menjadi bahasan bersama. Hubungan tersebut diatur dalam penerapan Corporate Social Responsibility (CSR) sejak tahun 1953 yang dikemukakan pertama kali oleh Bowen (Marthin dkk, 2017), sedangkan di Indonesia sendiri baru dibahas pada awal tahun 2000. CSR mengatur tentang tanggung jawab sosial yang dibebankan kepada perusahaan, dan dalam hal ini hotel sebagai perusahaan jasa termasuk ke dalam peraturan tersebut.

Peraturan tersebut didasarkan pada pembangunan perusahaan yang mengakibatkan dampak kepada masyarakat sekitar. Ambadar (2008) dalam penelitiannya mengemukakan bahwa orientasi pembangunan yang awalnya berfokus pada laba semata mulai beralih kepada upaya-upaya positif yang dapat memberikan kesejahteraan kepada masyarakat. Hal ini sesuai dengan kewajiban CSR sebagai komitmen dunia kerja untuk dapat mendukung peningkatan ekonomi, mengelola kualitas lingkungan hidup, dan kualitas sosial (sumber, tahun). Crowther, dll (2008) dalam Purwanto, dkk (2018) menambahkan tiga prinsip yang berlaku pada program ini, yaitu prinsip keberlanjutan, dapat diperhitungkan, dan proses yang transparan.

Selain itu, peraturan perundang-undangan yang mengatur jalannya program CSR terdapat pada UU No.40 Tahun 2007 tentang Perseroan Terbatas. CSR dimaksudkan sebagai Tanggung Jawab Sosial dan Lingkungan (TJSL) yang menyatakan bahwa:

"TJSL merupakan komitmen PT untuk berkontribusi dalam pembangunan ekonomi

berkelanjutan guna meningkatkan kualitas lingkungan hidup yang bermanfaat bagi

perseroan itu sendiri, komunitas setempat, hingga masyarakat secara luas."

(UU No.40 Tahun 2007 Pasal 74)

Dijelaskan lebih lanjut dalam PP 47 Tahun 2012 dengan ketentuan PT yang berkewajiban menjalankan TJSL adalah yang menjalankan usahanya pada bidang dan/atau yang bersinggungan dengan pengelolaan Sumber Daya Alam (SDA). PT yang dimaksudkan adalah PT yang kegiatan usahanya bergerak dalam pengelolaan dan pemanfaatan SDA, serta kegiatan usaha yang berpotensi dalam memberikan dampak pada fungsi daya dukung dan daya tampung lingkungan termasuk pelestarian lingkungan hidup.

Mengenai sektor jasa pariwisata, dalam hal ini perhotelan dijelaskan melalui Pasal 19 (2) yang menyatakan bahwa setiap masyarakat yang bertempat tinggal di sekitar destinasi pariwisata memiliki prioritas untuk menjadi pekerja. Dilanjutkan dalam pasal $26(\mathrm{G})$ dengan kewajiban perusahaan jasa pariwisata untuk mendahulukan penggunaan produk lokal dan kesempatan kerja pada pekerja lokal.

Sayangnya, peraturan tersebut tidak dilengkapi dengan anggaran minimal yang dibebankan pada PT sebagai CSR. Pada pasal yang sama ayat (2) menjelaskan bahwa pelaksanaan CSR dilakukan dengan memperhatikan kepatutan dan kewajaran. Hal ini tentu dapat menjadi bias dalam pelaksanaan program.

Untuk mengurangi bias yang ditimbulkan, penelitian ini bertujuan untuk mengetahui perbedaan implementasi pemerataan pembangunan melalui program CSR yang dilakukan di Kota Yogyakarta, dengan studi kasus dua hotel yang berbeda. Hotel yang terpilih adalah Hotel Tentrem sebagai perwakilan hotel bintang tinggi, dan hotel bintang rendah yang diwakilkan oleh Hotel Zest. Kedua hotel tersebut berada pada kawasan padat penduduk kota, sehingga program pemerataan pembangunan seharusnya dapat diterapkan dengan melihat objek yang ada.

\section{METODE}

Prosedur awal yang ditempuh dalam penelitian ini adalah mengumpulkan data pendukung berupa informasi awal dengan melakukan observasi dan wawancara pada kelurahan terkait yang berada di sekitar hotel amatan. Lokasi pengumpulan data berfokus pada lingkup RT 
setempat, dengan jumlah 30 responden pada masing-masing hotel. Lokasi tersebut tersebar di Kelurahan Cokrodiningratan, Kecamatan Jetis yang berada di lingkungan Hotel Tentrem, dan Kelurahan Purwokinanti, Kecamatan Pakualaman yang berada di lingkup Hotel Zest. Pengumpulan data dilakukan dalam rentang waktu dua hingga tiga bulan dengan bahan dan peralatan wawancara dan dokumentasi.

Untuk menentukan responden berdasarkan kriteria tertentu dilaksanakan dengan teknik purposive sampling (Sugiono, 2013). Rincian kriteria responden berupa: (1) masyarakat yang berada pada radius _m dari hotel amatan, (2) masyarakat berada pada kawasan padat penduduk yang sama di sekitar hotel, (3) merupakan perangkat desa terkait yang sudah dan/atau sedang menjabat selama pembangunan hotel tersebut berlangsung hingga saat ini, sehingga mengetahui secara pasti situasi yang terjadi. Selain sumber sekunder yang telah disebutkan, dibutuhkan sumber data primer yang berupa dokumentasi, sumber data jumlah masyarakat dan luas lokasi amatan, serta peraturan pendukung yang mengatur program sosial tersebut.

Dilanjutkan analisis menggunakan metode kualitatif dengan studi kasus. Fraenkel, dll (2012) menyatakan bahwa penelitian kualitatif mempertanyakan kualitas yang berhubungan dengan hubungan, aktivitas, situasi, dan/atau materi. Moleong (2014) menambahkan bahwa penelitian kualitatif bertujuan untuk mengetahui fenomena yang dialami oleh subjek penelitian secara holistik dengan penjelasan deskriptif dengan metode alamiah.

Mengenai uji validitas dalam penelitian kualitatif, metode yang digunakan adalah dengan menggunakan triangulasi sumber data dan metode. Triangulasi sumber data yang berasal dari data perangkat desa, masyarakat, dan peraturan perundang-undangan terkait. Triangulasi metode didapatkan dari observasi singkat, wawancara mendalam, dan dokumentasi sebagai data pendukung.

\section{HASIL DAN PEMBAHASAN}

Program CSR di Kota Yogyakarta diatur dalam Peraturan Daerah DIY Nomor 6 Tahun 2016 mengenai penyelenggaraan Tanggung Jawab Sosial dan Lingkungan Perusahaan (TSLP). Sayangnya, peraturan tersebut tidak bersifat mengikat. Tidak terdapat aturan baku mengenai besar minimum yang harus dikeluarkan oleh perusahaan. Peraturan tersebut menjelaskan bahwa:

"pembiayaan pelaksanaan program TSLP dialokasikan dari keuntugan bersih diluar pajak atau harus dialokasikan secara khusus dari mata anggaran lain yang ditentukan dengan memperhatikan kemampuan perusahaan, serta sesuai dengan ketentuan peraturan perundang-undangan"

Sedangkan peraturan perundang-undangan Pasal 74 ayat 2 UU 40/2007 hanya mewajibkan pelaksanaan TJSL dengan memperhatikan kepatutan dan kewajaran. Hal ini seharusnya dapat dimaksimalkan oleh pemerintah daerah DIY untuk menetapkan dan memberikan peraturan mengikat kepada perusahaan. Berbeda dengan Peraturan Daerah Provinsi Kalimantan Timur Nomor 3 Tahun 2013 tentang Tanggung Jawab Sosial dan Lingkungan Perseroan Terbatas serta Program Kemitraan dan Bina Lingkungan pasal 23 menyatakan bahwa pembiayaan pelaksanaan TJSL dialokasikan sebesar minimal 3\% dari keuntungan bersih perusahaan setiap tahunnya. Dengan diadakanya aturan penganggaran minimum, program CSR dapat dijalankan dengan lebih akuntabel dan dapat dipertanggungjawabkan.

Berdasarkan peraturan perundang-undangan tersebut, semakin besar cakupan usaha suatu perusahaan, maka akan semakin besar pula penerimaan manfaat dari program CSR. Pasalnya, semakin besar perusahaan, maka sumber daya yang digunakan semakin besar pula. Dengan resource dan penghasilan yang lebih besar, masyarakat penerima program CSR akan lebih luas.

Hal ini yang mendasari penelitian mengenai program CSR pada perusahaan akomodasi pariwisata hotel bintang tinggi yang diwakilkan oleh Hotel Tentrem dan bintang rendah yang 
diwakilkan oleh Hotel Zest. Kedua hotel ini dipilih berdasarkan kriteria: 1) berada pada kawasan padat penduduk, dengan kepadatan penduduk di atas rata-rata kepadatan kota; 2) berdiri dengan jangka waktu tidak lebih dari 10 tahun, sehingga masyarakat masih mengingat dan/atau mengalami dampak yang ditimbulkan; 3) merupakan hotel berbintang dengan dua konsep yang berbeda, hotel mewah dan hotel budget, sehingga diharapkan memiliki hasil program yang berbeda pula.

Pada penelitian ini, variabel ditentukan melalui kewajiban program CSR, meliputi: 1) kenaikan tingkat ekonomi; 2) perbaikan lingkungan; 3) perbaikan tingkat sosial. Aspek ekonomi ditentukan melalui kesempatan kerja, peluang usaha, dan kenaikan pendapatan. Sedangkan aspek lingkungan dilihat melalui sumber air dan pengolahan limbah. Terakhir, aspek sosial dinilai dari pembangunan fasilitas umum, pendampingan dan bantuan sosial yang berkelanjutan.

Sebagai gambaran awal, berikut dokumentasi eksisting dari dua kawasan amatan:

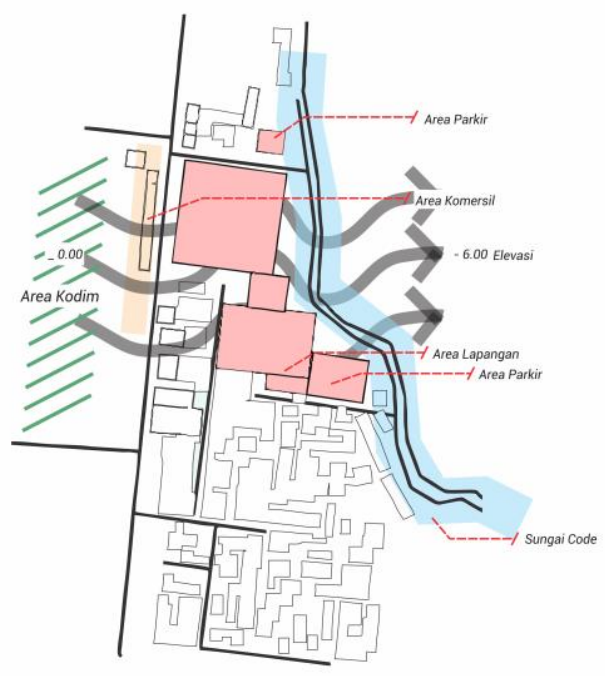

Gambar 1. Letak Hotel Tentrem dengan Kawasan Permukiman Sumber : Hasil Dokumentasi (2020)

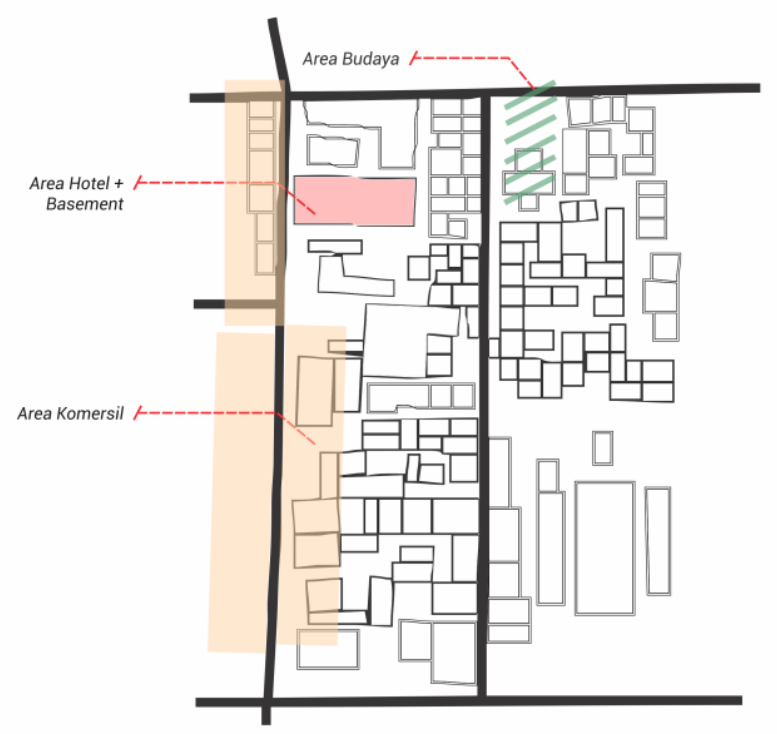

Gambar 2. Letak Hotel Zest dengan Kawasan Permukiman Sumber : Hasil Dokumentasi (2020) 


\section{Hasil}

Hotel Tentrem merupakan salah satu hotel bintang lima terbaik yang berada di Kota Yogyakarta. Dilengkapi dengan berbagai fasilitas pendukung, harga permalamnya juga tidak tanggung-tanggung. Berada di kawasan padat penduduk Kelurahan Cokrodiningratan Kecamatan Jetis, Hotel Tentrem memiliki tanggung jawab CSR yang cukup tinggi. Hasil observasi dan wawancara pada Hotel Tentrem dijawabrkan dalam poin berikut:

1. Kenaikan tingkat ekonomi

Kesempatan kerja di Hotel Tentrem tidak cukup tinggi, hal ini berlawanan dengan perjanjian kerja pada awal pembangunan. Respoden memaparkan bahwa terdapat batas minimum pendidikan yang ditetapkan, mengingat Hotel Tentrem sebagai hotel bintang lima. Jika pun ada dan memenuhi kualifikasi, ternyata tidak menjamin kesejahteraan pegawai tersebut. Gaji yang tidak standar dan tuntutan pekerjaan mengurangi minat warga untuk menetap dalam pekerjaan. $70 \%$ responden menjawab porsi pegawai yang menjadi porsi warga sekitar tidak terpenuhi.

Peluang usaha dan kenaikan pendapatan juga tidak terlalu signifikan dengan adanya hotel. Hal ini berkaitan dengan adanya gap sosial yang ada, Hotel Tentrem difungsikan sebagai hotel kelas menengah ke atas, sedangkan perekonomian masyarakat sekitar adalah menegah ke bawah. Meskipun masyarakat berpeluang untuk membuka usaha berbasis rumahan, penghuni hotel juga tidak memberikan sumbangsih dalam peningkatan perekonomian warga. Sama seperti kesempatan bekerja, $70 \%$ responden menjawab tidak ada korelasi antara keberadaan hotel dengan kenaikan pendapatan

Peluang kerja di Hotel Zest tidak berbeda jauh dengan Hotel Tentrem. Pasalnya, dari 35\% kesepakatan porsi pekerja lokal tidak dipenuhi oleh pihak hotel. Rekruitmen pada awal pembangunan dijanjikan oleh pihak kontraktor sebagai alasan untuk melancarkan proses pembangunan. Hal ini tidak sesuai dengan kode etik yang diwajibkan dalam program CSR. Selain itu,tidak adanya evaluasi dan kontrol dari pejabat daerah tidak dapat memperbaiki keadaan warga.

Pada aspek kenaikan penghasilan, 87\% responden menjawab tidak adanya kenaikan setelah terbangunnya hotel. Terdapat faktor yang berbeda dengan Hotel Tentrem, penghuni Hotel Zest (hotel budget) hanya menggunakan kesempatan menginap untuk sekadar singgah, dan bukan untuk explore kawasan sekitar yang dapat memberikan pendapatan lebih kepada usaha rumahan warga.

2. Perbaikan lingkungan

Peraturan Walikota Yogyakarta No.3 tahun 2014 mengenai penyediaan air baku usaha perhotelan di Kota Yogyakarta pada pasal 3 ayat 2 menjelaskan bahwa setiap usaha setiap usaha perhotelan di daerah yang terjangkau oleh jaringan Perusahaan Daerah Air Minum (PDAM) harus menyediakan air baku yang bersumber dari PDAM. Sedangkan pada pasal yang sama ayat 3 menyatakan bahwa setiap usaha perhotelan dapat mempergunakan sumber air tanah untuk tambahan penyediaan air baku dalam kegiatan usahanya. Dengan Perwali tersebut dapat kita simpulkan bahwa penggunaan air baku pada pengelola perhotelan mengunakan sekurangnya dua sumber air baku.

Hotel Tentrem mengundang sebagian warga sekitar untuk turut memantau penggalian sumur pada awal pembangunan. Hal ini merupakan kesepakatan kedua belah pihak mengenai sumber air. Hasil wawancara mencatatkan terdapat $50 \%$ masyarakat yang menyatakan sumber air yang digunakan Hotel Tentrem sudah sesuai dengan peraturan kota.

Berbeda dengan sumber air yang sesuai, lokasi Hotel Tentrem yang bersebelahan dengan Kali Code menyebabkan hasil pembuangan dari hotel terlihat dengan jelas. Meskipun beberapa warga mengatakan bahwa limbah yang terbuang sudah melalui proses pengolahan terlebih dahulu, beberapa waktu warna air limbah masih berwarna gelap. $60 \%$ hasil wawancara 
mengatakan bahwa limbah langsung dibuang ke sungai. Hal ini tidak sesuai dengan baku mutu air limbah yang tercatat dalam Peraturan Daerah DIY no.7 tahun 2016.

Hasil wawancara penggunaan sumber air baku pada Hotel Zest tidak lebih baik dari Hotel Tentrem. Hanya $43 \%$ responden yang mengatakan bahwa penggunaan air baku Hotel Zest sudah sesuai. Hal ini dikarenakan tidak adanya pengawasan dari warga sekitar pada awal pembangunan. Meskipun begitu, responden memaparkan bahwa mayoritas warga menggunakan PDAM sebagai sumber air baku, sedangkan pihak hotel menggunakan sumber air dari sumur bor dalam sehingga penggunaan air dari hotel tidak berpengaruh signifikan.

Hasil yang sama pada pengolahan air limbah di Hotel Zest, hanya $43 \%$ responden menjawab pengolahan limbah sudah sesuai. Terdapat permasalahan pembuangan limbah pada awal pembangunan hotel, berupa macet dan sering buntu. Hal ini selanjutnya diurus oleh pemerintah daerah dengan penyediaan bak kontrol baru. Pemerintah dalam hal ini mengambil alih tanggung jawab yang seharusnya dibebankan kepada pihak hotel.

3. Perbaikan sosial

Perbaikan lingkungan, dalam hal ini kewajiban sosial yang dibebankan dalam program CSR dilihat dari dua variabel yaitu fasilitas atau infrastruktur umum dan bantuan sosial. Pada Hotel Tentrem, tidak ada fasilitas berupa pengadaan fasilitas umum/sosial. Namun karena adanya penggusuran mushola pada lahan yang digunakan hotel, warga mengajukan usulan penggantian mushola. $60 \%$ responden menjawab tidak ada fasilitas umum baik berupa jalan, penerangan, maupun fasilitas lainnya.

Untuk bantuan sosial terdapat beberapa program yang masih berjalan di Hotel Tentrem, diantaranya adalah stimulant untuk posyandu berupa konsumsi, pemberian hewan kurban pada saat Idul Adha, dan hadiah 17an setiap tahun yang diajukan oleh perangkat desa setempat melalui proposal. Bantuan yang diberikan merupakan jenis bantuan yang diberikan berulang, namun tidak bersifat berkelanjutan. Bantuan bukan merupakan program pemberdayaan yang dapat mengembangkan potensi yang dimiliki masyarakat. Meskipun begitu bantuan sosial cukup merata, $60 \%$ responden menjawab mendapatkan bantuan.

Tabel 1. Program CSR pada Hotel Tentrem dan Zest

\begin{tabular}{|c|c|c|c|c|c|c|c|c|}
\hline \multirow[b]{2}{*}{ No } & \multirow[b]{2}{*}{$\begin{array}{c}\text { Aspek } \\
\text { Penilaian }\end{array}$} & \multirow[b]{2}{*}{ Variabel } & \multicolumn{3}{|c|}{ Hotel Tentrem } & \multicolumn{3}{|c|}{ Hotel Zest } \\
\hline & & & $\begin{array}{c}\text { Di } \\
\text { bawah } \\
50 \%\end{array}$ & $50 \%$ & $\begin{array}{c}\mathrm{Di} \\
\text { atas } \\
50 \% \\
\end{array}$ & $\begin{array}{c}\text { Di } \\
\text { bawah } \\
50 \% \\
\end{array}$ & $50 \%$ & $\begin{array}{c}\text { Di } \\
\text { atas } \\
50 \%\end{array}$ \\
\hline \multirow{2}{*}{1} & \multirow{2}{*}{ Ekonomi } & \multirow{6}{*}{$\begin{array}{l}\text { Perekrutan } \\
\text { Pegawai } \\
\text { Kenaikan } \\
\text { Pendapatan } \\
\text { Sumber Air Baku } \\
\text { Pengolahan } \\
\text { Limbah } \\
\text { Fasilitas Sosial } \\
\text { Bantuan Sosial }\end{array}$} & V & & & $\sqrt{ }$ & & \\
\hline & & & V & & & V & & \\
\hline 2 & LIngkungan & & & $\sqrt{ }$ & & $\mathrm{V}$ & & \\
\hline \multirow[t]{4}{*}{3} & Sosial & & $\mathrm{V}$ & & & $\mathrm{V}$ & & \\
\hline & & & $\sqrt{ }$ & & & $\mathrm{V}$ & & \\
\hline & & & & & $\mathrm{v}$ & & & $v$ \\
\hline & Jumlah & & 4 & 1 & 1 & 6 & - & 1 \\
\hline
\end{tabular}

Sumber : Hasil Wawancara (2020)

Hasil perbaikan sosial Hotel Zest tidak jauh berbeda dari hasil Hotel Tentrem. Untuk fasilitas sosial tidak ada program pengadaan dari pihak hotel. Hal ini terkait letak pagar keliling hotel yang langsung bersebelahan dengan dinding rumah warga, tidak dibatasi dengan jalan atau lahan lain. $70 \%$ responden menjawab tidak ada fasilitas sosial, sisanya mendapatkan fasilitas berupa penerangan yang terbatas dari pagar keliling hotel. 
Untuk bantuan sosial, 57\% warga menjawab mendapatkan bantuan. Bantuan sosial yang diberikan Hotel Zest berupa hewan kurban, stimulan posyandu, dan perayaan ulang tahun Hotel Zest yang melibatkan warga dengan mengadakan lomba tumpeng. Cakupan bantuan sosial yang diberikan tidak terlalu luas, tergantung pada radius kedekatan hunian warga dengan bangunan hotel. Pembagian bantuan sosial juga berdasarkan Rukun Tetangga terdekat dengan hotel.

Baik Hotel Tentrem maupun Hotel Zest, aspek sosial yang diberikan tidak jauh berbeda. Tidak ditemukan program-program berkelanjutan yang bersifat pemberdayaan warga. Rekapitulasi aspek ekonomi, lingkungan, dan sosial di kedua hotel dirangkum dalam Tabel 1.

\section{Pembahasan}

Hasil wawancara dan observasi lapangan mengenai program CSR di Hotel Tentrem dan Hotel Zest tidak memberikan hasil yang memuaskan. 1) Tidak ditemukan program perbaikan ekonomi melalui perekrutan pekerja maupun penyediaan peluang usaha; 2) Pada aspek perbaikan lingkungan berupa pengadaan air baku dan pengolahan limbah, sumber air baku yang didapatkan Hotel Tentrem lebih sesuai peraturan daerah setempat, sedangkan pengolahan limbah sama buruknya dengan Hotel Zest. Tidak ada upaya perbaikan lingkungan lain yang ditemukan; 3) perbaikan sosial yang dijalankan kedua hotel tidak jauh berbeda. Tidak ditemukan program pemberdayaan berkelanjutan yang diwajibkan pada program CSR.

Program yang dijalankan kedua hotel belum mencerminkan pemerataan pembangunan melalui program CSR. Padahal, pelaksanaan program CSR yang baik dapat mendukung pemerataan pembagunan. Hal ini sejalan dengan penelitian yang disampaikan oleh Wahyuningrum (2014), bahwa pelaksanaan program CSR secara simultan ataupun parsial dapat memberikan pengaruh baik kepada masyarakat sekitar berupa pemberdayaan. Sayangnya, program yang dijalankan masih sebatas pemenuhan kewajiban minimum perusahaan. Hal ini sejalan dengan penelitian Purwantoro, dkk (2018) bahwa program CSR sebatas upaya pemenuhan kewajiban, dan hanya ditujukan untuk peningkatan reputasi dan keuntungan perusahaan.

Perlunya partisipasi masyarakat dalam pemenuhan program-program CSR, yang berlandaskan azas dari dan untuk masyarakat itu sendiri. Hal ini dapat dijalankan dengan kelembagaan yang berkelanjutan, sesuai dengan penjelasan Mardikanto (2010) bahwa partisipasi masyarakat dalam kegiatan CSR dapat meningkatkan sentimen positif dengan mempertimbangkan ragam kegiatan dan partisipasi masyarakat yang terus meningkat. Meskipun telah ada beberapa program CSR yang dijalankan, namun program tersebut tidak memenuhi kriteria pemerataan pembangunan jangka panjang.

Hadi (2014) menjelaskan bahwa pelaksanaan program CSR dapat dijalankan dengan pembentukan satu divisi khusus dalam penanganan pemberdayaan masyarakat sehingga kebutuhan masyarakat dapat terakomodasi dengan baik. Dalam penelitian ini, aspek ekonomi berupa pekerjaan dan pendapatan tidak tercapai. Aspek lingkungan hidup melalui peraturan air dan limbah, Hotel Tentrem mendapatkan hasil yang lebih baik. Dan yang terakhir mengenai aspek sosial hanya terdapat bantuan sosial yang bersifat charity, dan bukannya pemberdayaan. Hal ini masih jauh dari target penerapan program CSR seperti yang dipaparkan Mapisangka (2009) yang menyimpulkan bahwa penerapan program CSR dapat dijalankan pada beberapa aktivitas untama, diantaranya kemiskinan, pendidikan, kesehatan, infrastruktur, lingkungan hidup, sosial, dan agama. Namun, menurut Apsari (2012) mayoritas perusahaan bisnis perhotelan di Yogyakarta mendefinisakan program CSR sebagai corporate philanthropy, dengan isu sosial sebagai fokus utama.

Dengan hasil penelitian yang didapatkan dan komparasi dengan penelitian serupa pada masa lampau, program CSR pada Hotel Tentrem dan Hotel Zest belum dapat dikatakan 
maksimal. Hal ini sangat disayangkan, karena dari pihak masyarakat sendiri terdapat kemauan untuk dibina dan diberdayakan. Masyarakat bersedia untuk turut bekerja, hal ini dapat dilihat pada awal pembangunan terdapat antusias masyarakat untuk bergabung namun terbentur dengan kualifikasi yang ada. Beberapa masyarakat bahkan bersedia jika diminta untuk turut memperbaiki lingkungan sekitar hotel, misalkan penanaman tanaman pangan pot di sekeliling pagar hotel. Selain dapat memperbaiki tampilan hotel, pandangan masyarakat juga tidak terpaku pada dinding raksasa polos yang mengelilingi lingkungan. Selain hotel dapat manfaat dari perbaikan estetika, masyarakat juga dapat memanfaatkan lahan tersebut menjadi sumber tanaman pangan. Masih banyak hal yang dapat digali oleh perusahaan dalam pelaksanaan program CSR, terutama program pada lokasi pada penduduk.

\section{KESIMPULAN}

Berdsarkan hasil penelitian yang didapatkan, program tanggung jawab sosial berupa 1) kenaikan tingkat ekonomi; 2) perbaikan lingkungan; 3) perbaikan tingkat sosial pada Hotel Tentrem dan Hotel Zest belum maksimal. Banyak hal yang masih dapat digali melalui potensi masyarakat setempat. Adanya keinginan masyarakat untuk turut memajukan lingkungan sekitar seharusnya dapat dimanfaatkan dengan baik oleh pihak perusahaan. Pemerataan pembangunan yang baik dapat tercapai jika hak dan kewajiban seluruh stakeholder terkait dapat diposisikan sesuai porsi masing-masing pihak. Sesuai dengan penelitian Mardikanto (2010) bahwa pemberdayaan seharusnya dijalankan secara terarah dan secara lansung ditujukan kepada pihak yang membutuhkan, serta dirancang sebagai problem solving dalam barbagai masalah yang ada. Masih banyak program pemerataan pembangunan yang dapat dijalankan melalui program CSR, seperti yang dijelaskan Apsari (2012) selain program sosial terdapat program kemiskinan, pendidikan, kesehatan, infrastruktur, lingkungan hidup, dan agama.

\section{REKOMENDASI}

Alternatif program dan kebijakan dari program CSR Hotel Tentrem dan Hotel Zest adalah sebagai berikut:

a. Pemberdayaan peningkatan ekonomi terpadu masyarakat melalui pembinaan UMKM, sertifikasi keahlian, dan peningkatan taraf ekonomi melalui perbaikan pendidikan dan kesehatan;

b. Pemerataan pembangunan fisik melalui pembangunan infrastruktur sosial, perbaikan lingkungan hidup dengan pengolahan limbah yang berkelanjutan;

c. Peningkatan kualitas sosial melalui komunikasi dan partisipasi masyarakat, bantuan sosial pada saat peaksanaan kegiatan sosial kemasyarakatan;

d. Program yang telah dijalankan, dilanjutkan dan dikonversi ke dalam kegiatan yang lebih berkelanjutan dan bermanfaat bagi kedua belah pihak, dan pemerintah;

e. Perlunya evaluasi dan kontrol secara berkelanjutan dari pemerintah daerah setempat mengenai pelaksanaan program CSR, dengan melibatkan seluruh stakeholder terkait.

\section{UCAPAN TERIMAKASIH}

Alhamdulillah atas terselesaikannya jurnal ini. Ucapan terimakasih kepada seluruh pihak yang berkontribusi dalam penelitian ini, diantaranya dosen pembimbing, masyarakat sebagai respnden, dan perangkat desa terkait sebagai validasi hasil penelitian. tidak lupa dukungan moril dan materiil dari keluarga, teman seperjuangan, dan diri sendiri atas perjuangannya.

\section{DAFTAR PUSTAKA}

Ambadar, J. (2013). CSR Dalam Praktik Di Indonesia. Elex Media Komputindo. 
Apsari, A. A., \& Rohman, A. (2012). Perspektif Pelaku Bisnis Perhotelan di DI Yogyakarta terhadap CSR. Jurnal Komunikasi, 7(1), 43-54.

Crowther, D. (2008). Corporate social responsibility. Bookboon.

Daerah Istimewa Yogyakarta. (2016). Peraturan Daerah Daerah Istimewa Yogyakarta Nomor 6 Tahun 2016 Tentang Penyelenggaraan Tanggung Jawab Sosial Dan Lingkungan Perusahaan.Yogyakarta.

Daerah Istimewa Yogyakarta. (2016). Peraturan Daerah Istimewa Yogyakarta Nomor 7 Tahun 2016 Tentang Baku Mutu Air Limbah. Yogyakarta

Daerah Provinsi Kalimantan. (2013). Peraturan Daerah Provinsi Kalimantan Timur Nomor 3 Tahun 2013 tentang Tanggung Jawab Sosial dan Lingkungan Perseroan Terbatas. Provinsi Kalimantan Timur.

Mapisangka, A. (2009). Implementasi CSR terhadap kesejahteraan hidup masyarakat. Jurnal Ekonomi dan Studi Pembangunan, 1(1).

Marthin; Salinding, Marthen B.; Akim, Inggit. (2017). Implementasi Prinsip Corporate Social Responsibility (CSR) Berdasarkan Undang-Undang Nomor 40 Tahun 2007 tentang Perseroan Terbatas. J. Priv. \& Com. L., 1, 111.

Mardikanto, T., Lestari, E., Anantanyu, S., \& Saddhono, K. (2010). Konsep-konsep pemberdayaan masyarakat: acuan bagi aparat birokrasi, akademi, praktisi, dan peminat/pemerhati pemberdayaan masyarakat. Fakultas Pertanian UNS.

Moleong, L. J. (2014). Metodologi Penelitian Kuantitatif dan Kualitatif, PT Remaja Rosdakarya.

Purwanto, P., Suhardjanto, D., Warto, W., \& Supriyadi, S. (2018). Existing Program Tanggung Jawab Sosial (Csr) Hotel Berbintang Terhadap Masyarakat Di Kota Surakarta.

Republik Indonesia. (2007). Undang-Undang Nomor 40 Tahun 2007 Tentang Perseroan Terbatas. Jakarta.

Sugiyono. (2013). Metode Penelitian Kuantitatif, Kualitatif dan $R \& D$ (13th ed.), CV. Alphabeta, Bandung.

Wahyuningrum, Y. (2014). Pengaruh Program Corporate Social Responsibility Terhadap Peningkatan Pemberdayaan Masyarakat (Studi Pada Implementasi CSR PT. Amerta Indah Otsuka Desa Pacarkeling Kecamatan Kejayan Kabupaten Pasuruan). Jurnal Administrasi Publik, 2(1), 109-115.

Yogyakarta, Peraturan Walikota. (2014) " Penyediaan Air Baku Usaha Perhotelan di Kota Yogyakarta." 